\title{
Structuring hotel deals to achieve strategic goals: An owner's perspective
}

Received: 8 February 2004

\section{Geoffrey Davis}

is President of HREC Investment Advisors. Geoff has over 20 years of hospitality industry experience and is regarded as one of the top dealmakers and investment advisers in the hotel industry, having closed over 150 transactions with a market capitalisation in excess of $\$ 1.7 \mathrm{bn}$. Geoff is a member of the International Society of Hospitality Consultants and has been involved as a hotel owner, including investment partnerships with large institutional investors and private individuals.

\section{Jan A. deRoos}

is the HVS International Professor of Hotel Finance and Real Estate at the Cornell University School of Hotel Administration. On the faculty of the Hotel School since 1988 , he has devoted his career to research and teaching in the area of hospitality real estate, with a focus on hotel valuation and investment decision making. Prior to joining Cornell University, Jan worked extensively in the hospitality industry. His current research interests concentrate on lodging property investment, valuation and the control of lodging property via leases and management contracts.

\section{Abstract}

Purchases and sales of hotels are much more than conversions of real estate assets into a more liquid form. Deal structure provides important and indispensable strategic options to buyers and sellers, and can be used to help owners of property achieve multiple goals through the sale. This paper provides a theoretical framework for strategic deal structuring and illustrates the theory with a recent deal that exemplifies the creative nature of the opportunities available.

\section{Keywords:}

hotel deals, hotel investing, deal structure, lodging investment, value creation, hotel ownership

Geoffrey Davis

President

HREC Investment Advisors

6400 S. Fiddler's Green Circle

Suite 1730

Englewood, CO 80111, USA

Tel: +1 3032670057

Fax: +13032670105

E-mail: gdavis@hrec.com

Jan A. deRoos

School of Hotel Administration

Cornell University

435 Statler Hall

Ithaca, NY 14853-6902, USA

Tel: +16072558716

E-mail: jad10@cornell.edu

\section{INTRODUCTION}

Savvy owners understand that engineering deal structure to meet strategic goals is an important and indispensable part of the acquisition and disposition cycle. This paper explores the topic of deal structuring from a theoretical and practical point of view and gives specific advice on how owners can achieve strategic goals. The theoretical discussion provides a framework for understanding the deal structuring choices and opportunities available to investors. The paper continues with an example of a recent deal that illustrates how the framework is creatively applied to achieve specific objectives. 


\section{Deal structuring overview}

\section{DEAL STRUCTURING}

The theoretical overview of deal structuring starts with a brief review of the five fundamental real estate strategies for value creation. ${ }^{1}$ Although the strategies will be characterised individually, they are not mutually exclusive, and can be combined.

- Create value via development or redevelopment. The business model is to create properties whose actual costs are less than the market value of the project upon completion. While development is very straightforward, redevelopment can take many forms: renovation, repositioning and change of use (eg office building to lodging). Successful developers understand the risks of creating or redeveloping property when evaluating opportunities, as the risks of a failed development have the potential to be very costly, both in terms of monetary losses and in loss of reputation.

- Create value by using superior operating skills to enhance revenues and operate more efficiently than competitors, producing superior net operating income (NOIs). The difficulty with this strategy is that the market may not pay for the superior NOI upon sale, if it is not transferable with the property. If the superior NOI is captured only by the current owner, this strategy maximises value only with a long holding period.

- Create value via a lower cost of capital; this is a particularly powerful advantage, as it allows one to outbid rivals without taking on incremental risk. History has shown that a long-term advantage in the capital market is difficult to sustain, although it is possible to raise large sums for acquisition in the short term; as demonstrated by the US lodging real estate investment trusts (REITs) in the mid-1990s and the European property funds via sale-leasebacks in 2000 and 2001.

- Create value with superior investing skills, such as enhanced selection procedures and the ability to time the market. Successful investors avoid two kinds of errors: the first is to avoid investing in a bad deal; the second error is to 'pass' on a potentially good deal. In many ways, the second error is more serious if it is done systematically. Market timing strategies are driven by an understanding of long-term fundamentals and the ability to buy hotels as a contrarian, when the rest of the market is shunning them or undergoing liquidity crises, and to sell them when the market is embracing hotel property investments. One argument against market timing is that it appears that the volatility of hotel prices over the business cycle may be moderating, reducing the potential returns to a timing strategy.

- Create value by systematically embracing risk; the classic strategy is adding debt capital to leverage equity returns. Since increasing leverage is a deliberate strategy to enhance returns by embracing risk, one must have a proper risk-adjusted benchmark to 
determine if the strategy is successful. One would expect a property leveraged at 75 per cent to have a higher equity yield than a property leveraged at 60 per cent - the question is whether the extra yield compensates for the additional risks.

\section{Proper structuring enhances returns}

\section{Six 'big questions'}


Table I: Summary of how the six big questions influence the five strategies

\begin{tabular}{|c|c|c|c|c|c|c|}
\hline & Holding period & Partners & Capital structure & Asset management & Exit strategy & Tax consequences \\
\hline Development & $\begin{array}{l}\text { Short-term hold, by } \\
\text { definition, can be } \\
\text { combined with the } \\
\text { operating skills or } \\
\text { lower cost of capital } \\
\text { strategies to achieve } \\
\text { a long-term holding } \\
\text { strategy. }\end{array}$ & $\begin{array}{l}\text { Partnership is part of } \\
\text { the strategy: build to } \\
\text { partner standards to } \\
\text { maximise NOls. } \\
\text { Depending on the } \\
\text { exit strategy, } \\
\text { terminable contracts } \\
\text { may be desired. }\end{array}$ & $\begin{array}{l}\text { Value is created } \\
\text { through development } \\
\text { skills; use maximum } \\
\text { leverage to achieve } \\
\text { high return on equity } \\
\text { investment. }\end{array}$ & $\begin{array}{l}\text { Unimportant in the } \\
\text { development phase. } \\
\text { The key is well- } \\
\text { developed project } \\
\text { management skills. }\end{array}$ & $\begin{array}{l}\text { If the exit strategy is } \\
\text { to sell upon } \\
\text { completion, the } \\
\text { project is structured to } \\
\text { be easily transferred. } \\
\text { In fact, the 'take-out' } \\
\text { is often structured as } \\
\text { part of a complete } \\
\text { package deal. }\end{array}$ & $\begin{array}{l}\text { Capital gains taxes and } \\
\text { transfer taxes are the } \\
\text { dominant concerns. }\end{array}$ \\
\hline Operating skills & Long-term hold. & $\begin{array}{l}\text { Long-term contracts, } \\
\text { total fees tie to } \\
\text { performance. Can } \\
\text { give up the option } \\
\text { to cancel and gain } \\
\text { other concessions. }\end{array}$ & $\begin{array}{l}\text { Optimal capital } \\
\text { structure depends } \\
\text { on the cost and } \\
\text { availability of debt } \\
\text { and equity capital. }\end{array}$ & $\begin{array}{l}\text { Well-developed asset } \\
\text { management skills will } \\
\text { enhance returns as } \\
\text { increases in NOls are } \\
\text { fully captured by the } \\
\text { current owner and } \\
\text { are transportable to } \\
\text { other acquisitions. }\end{array}$ & $\begin{array}{l}\text { Use sales to stabilise } \\
\text { cash flows across a } \\
\text { portfolio, and } \\
\text { neutralise business } \\
\text { cycle risk. Purchases } \\
\text { and sales proceed } \\
\text { slowly, but } \\
\text { continuously, } \\
\text { disposing of ageing } \\
\text { properties and } \\
\text { purchasing new } \\
\text { ones to refresh the } \\
\text { portfolio. }\end{array}$ & $\begin{array}{l}\text { Long-term holding } \\
\text { periods create } \\
\text { significant capital gains. } \\
\text { A tax-free exchange } \\
\text { can drastically impact } \\
\text { on returns. Transfer } \\
\text { taxes may be a } \\
\text { significant factor } \\
\text { impacting on the exit } \\
\text { strategy. }\end{array}$ \\
\hline $\begin{array}{l}\text { Lower cost of } \\
\text { capital }\end{array}$ & Long-term hold. & $\begin{array}{l}\text { Long-term contracts, } \\
\text { total fees tie to } \\
\text { performance. Can } \\
\text { give up the option to } \\
\text { cancel and gain other } \\
\text { concessions. }\end{array}$ & $\begin{array}{l}\text { Maximise the use of } \\
\text { low-cost debt or } \\
\text { equity capital to } \\
\text { achieve a superior } \\
\text { weighted average } \\
\text { cost of capital } \\
\text { (WACC). }\end{array}$ & $\begin{array}{l}\text { Well-developed asset } \\
\text { management skills will } \\
\text { enhance returns as } \\
\text { increases in NOls are } \\
\text { fully captured by the } \\
\text { current owner and } \\
\text { are transportable to } \\
\text { other acquisitions. }\end{array}$ & $\begin{array}{l}\text { Use sales to stabilise } \\
\text { cash flows across a } \\
\text { portfolio, and } \\
\text { neutralise business } \\
\text { cycle risk. Purchases } \\
\text { and sales proceed } \\
\text { slowly, but } \\
\text { continuously, } \\
\text { disposing of ageing } \\
\text { properties and } \\
\text { purchasing new } \\
\text { ones to refresh the } \\
\text { portfolio. }\end{array}$ & $\begin{array}{l}\text { Long-term holding } \\
\text { periods create } \\
\text { significant capital gains. } \\
\text { A tax-free exchange } \\
\text { can drastically impact } \\
\text { on returns. Transfer } \\
\text { taxes may be a } \\
\text { significant factor } \\
\text { impacting on the exit } \\
\text { strategy. }\end{array}$ \\
\hline Market timing & Short-term hold. & $\begin{array}{l}\text { Structure contracts } \\
\text { with termination } \\
\text { contracts if likely } \\
\text { buyers desire } \\
\text { unencumbered assets. }\end{array}$ & $\begin{array}{l}\text { Capital structure is } \\
\text { less important to } \\
\text { overall success; } \\
\text { strategy is driven by } \\
\text { market mis-pricing, } \\
\text { not capital structure. }\end{array}$ & $\begin{array}{l}\text { Asset management } \\
\text { skills less important } \\
\text { due to short-term } \\
\text { holding period. }\end{array}$ & $\begin{array}{l}\text { Exit timing is critical, } \\
\text { driven by the } \\
\text { business cycle. Sell } \\
\text { far enough in advance } \\
\text { of the peak to sell } \\
\text { 'upside' to potential } \\
\text { buyers, not so far in } \\
\text { advance as to leave } \\
\text { 'money on the table'. }\end{array}$ & $\begin{array}{l}\text { Capital gains taxes and } \\
\text { transfer taxes are the } \\
\text { dominant concerns. }\end{array}$ \\
\hline Leverage driven & $\begin{array}{l}\text { Short-term hold, } \\
\text { especially if a lot of } \\
\text { the yield comes from } \\
\text { an initial increase in } \\
\text { value. }\end{array}$ & $\begin{array}{l}\text { Structure contracts } \\
\text { with termination } \\
\text { contracts if likely } \\
\text { buyers desire } \\
\text { unencumbered assets. }\end{array}$ & $\begin{array}{l}\text { Conscious strategy to } \\
\text { use leverage or } \\
\text { gearing to increase } \\
\text { equity yields. }\end{array}$ & $\begin{array}{l}\text { Asset management } \\
\text { skills less important } \\
\text { due to short-term } \\
\text { holding period. }\end{array}$ & $\begin{array}{l}\text { If a lot of the yield } \\
\text { comes from an initial } \\
\text { increase in value the } \\
\text { exit timing is not } \\
\text { driven by the cycle, } \\
\text { rather the desire to } \\
\text { enter and exit the } \\
\text { market quickly to } \\
\text { maximise equity } \\
\text { returns. }\end{array}$ & $\begin{array}{l}\text { Capital gains taxes and } \\
\text { transfer taxes are the } \\
\text { dominant concerns. }\end{array}$ \\
\hline
\end{tabular}

\section{Holding period}

The holding period decision is driven from the buyer's strategy, as noted above. Understanding the holding period forces buyers to

\section{Exit strategy drives holding period} think about the exit and the exit strategy. It is a serious blunder to make acquisition decisions supported by a 'standard' ten-year analysis template when the anticipated holding period is shorter or 
Brand and management contract

\section{Debt and equity capital}

longer than ten years. Buyers should anticipate both the expected set of buyers upon exit and the expected selling price to these buyers, and not rely on the appraiser's opinion of the 'market value' to define the exit. The development strategy can be coupled with short- or long-term holding periods, depending on the developer's strategic objectives.

Holding periods of investors using operating skills and a low cost of capital are long by definition; maximising long-term NOI is the nature of the strategy. On the other hand, the market timing and leverage-driven strategies are consistent with short holding periods, as internal rates of return (IRRs) are maximised by executing a sale, not by focusing on property cash flows.

\section{Partners}

Very few brands or managers develop their own properties, relying instead on experienced developers to bring the product to market. Some developers prefer to retain their own management and purchase a franchise to obtain the brand, while others simply make a development profit, selling assets upon completion and allowing the new owners to make the brand and management decisions.

Investors using the operating skills and lower cost of capital strategies can use the long-term contracts preferred by most managers; in exchange these owners should be sure to tie contract renewal to performance and obtain transparency in system reimbursables.

It is critical that market timers and leverage-driven investors obtain the right to terminate the brand and/or management agreements, especially if the exit strategy hinges on selling the asset unencumbered. One will pay dearly for the right to terminate, but this is much better than relying on the ability to terminate unilaterally, which can be successfully challenged in the courts.

\section{Capital structure}

There are clear differences in strategy as it relates to capital structure. Developers can embrace debt capital to maximise their equity returns, as the build-and-sell strategy has a short holding period conducive to high IRRs. The optimal capital structure for the operating skills and low cost of capital strategies depend critically on current capital market conditions; for example, the life insurance industry has used its position to offer attractively priced debt capital to take a position in the lodging industry. Many investment funds have developed low-cost equity capital - current examples are the German open-ended funds and the US private REITs.

Market timers are generally focused on the timing of buying and selling; the capital structure becomes a tactical not a strategic issue. Leverage-driven investors, on the other hand, use debt capital strategically to enhance equity returns. 


\section{Positioning assets for exit}

\section{Asset management}

Effective asset management skills are most productive in a longterm holding period strategy, notably the operating skills and the low cost of capital strategies. The long holding period gives these investors the ability to capture the investments fully in maximising NOI. Those with short holding periods benefit less from investments in maximising NOI that may not be transferable to new owners.

\section{Exit strategy}

One must thoroughly understand the potential exit or exits as part of the purchase decision. Positioning an asset for a 'facilitated transfer' is important for short-holding-period investors, to maximise the yield. A six-month delay (to 'unwind' a complex ownership structure, for example) on a three-year hold can significantly impact on the equity IRR; the same delay on a 15-year hold is much less consequential.

One must understand who the potential buyers might be, so as to structure the deal appropriately; REITs are looking for relatively high current yield and may be willing to trade some 'upside potential' for stable cash flows. Opportunistic investors, on the other hand, are willing to trade low current cash flow for significant 'upside potential'.

\section{Tax consequences}

Short-term holding periods make transaction taxes a significant impact on overall yields, while these are less important in a longholding-period strategy. Long holding periods generally give rise to large capital gains; sellers may be interested in tax-free exchanges or other means to defer and time taxes, such as an instalment sale or a US private REIT transfer.

\section{CURRENT STRUCTURES AND STRATEGIES}

Based on the current depressed state of the US hotel industry, a variety of deal structures and strategies are being employed to create value and achieve hotel owners' strategic goals.

\section{Refinance versus sale}

Interest rates for hotel debt are at the lowest level in 40 years. As such, it is possible to take advantage of interest rates as a form of subsidy to help prop up the returns of a hotel investment until market conditions improve to the level that would provide for an advantageous sale. An evaluation of supportable debt must be made based on current cash flow, the ability and willingness of an owner to take recourse on the debt and the perceived quality level and experience of the sponsor. Impediments to refinance to take advantage of low rates would be current loan restrictions, such as lock-out provisions that prevent the ability to refinance, or onerous prepayment penalties that make this strategy unfeasible. In such cases, a sale may be the best course of action, even if it may 


\section{Capital structure issues}

\section{Structuring non- performing asset transactions}

produce a loss on the investment. The owner must assess if the situation can be corrected via property or market improvements, and whether or not a delay in choosing to sell an asset will produce a more dramatic loss in the future.

\section{Mezzanine debt/preferred equity versus traditional equity}

The use of mezzanine debt or preferred equity has gained favour as hotel lenders have reduced their loan-to-value ratios on first mortgages to reduce their risk exposure. Preferred equity is essentially another form of mezzanine debt, with the exception that it provides for liens or encumbrances against the partnership interest holding the asset, versus a recorded lien on the title of a hard asset. It provides for a path to the title in the event of a default, and is often utilised when the first mortgage has covenants that prevent second mortgages. The cost of mezzanine financing is high, with current rates of 12-14 per cent, plus a look-back return that generates a yield of 18-22 per cent. By using a look-back structure, the mezzanine lender gets a 'kicker' that increases the yield on their initial loan upon a sale or refinance. This allows the borrower to keep the current cost of the loan down, but takes away a portion of their upside in a transaction. Historically, hotel owners who were capital constrained could either utilise their primary lender to increase their leverage or increase the direct equity investment via their own resources or additional investors. The fundamental question is which strategy is more profitable. The cost of mezzanine financing in the long run will be less expensive than traditional equity investment if the project is successful. But the increased leverage a project must support adds a level of risk to the investment that must be weighed in the mind of the investor.

\section{A piece of something versus all of nothing}

One of the great predicaments for hotel owners in the current environment is not so much what to do with assets that are performing, but what to do with assets that have negative cash flow or are not meeting expectations in general. Rather than turn the keys back to the lender, or force a sale at a price that does not achieve the original objectives of the investment, the use of partial sales or structured joint ventures should be a consideration. There is considerable capital today seeking investment in the hospitality sector. Much of this capital is institutional in nature and, as such, is risk-averse. Thus, while hotels present a tremendous contrarian play in the current economic climate, a great deal of the capital seeking that play either does not really understand the hospitality business or is generally risk-averse. As such, the opportunity exists to structure transactions that protect the investor in an asset via the use of preferred returns, lower initial valuations, specific disposition strategies or other methods in exchange for a greater upside in future revenues to the original owner. Such returns are often subordinated to a threshold level of return to the fresh capital, and 


\section{Buyers are marginal optimists}

\section{Sellers can profit from timing their exit}

are thus called a promoted equity interest to the new investor. In such cases, it is often the responsibility of the sponsor/operating partner to employ a business strategy that will produce not only the minimum level of return for the new investor, but also the results that will produce the promoted return for themselves.

\section{The buy side of a transaction - Predicting the future}

As stated earlier, one of the true art forms in real estate investing is being able to make good, risk-adjusted decisions based on a certain expectation of the future. These expectations can take many forms; for example, one might expect that a performing asset will hold steady; or one could expect that the combination of management, development and capital structuring skills will create incremental value; and one could predict that macro impacts such as local, national or worldwide economic and demographic factors will improve to the level that they will benefit a single asset. Such assessments are difficult, and they always involve a certain amount of faith and good fortune on the part of an investor. Experienced hotel investors often make informed decisions based on the facts and their experience, however, and must guess right more often than not, or they are quickly exited from the playing field.

\section{The sell side - Timing is everything}

Many owners of hotel assets are constrained by outside factors that influence when they must exit an asset. An example would be closed-end opportunity funds that have a limited life, and as such need to sell their holdings within a certain time frame. Other factors could be maturing loan dates, a partner who wants to exit an asset, or the need to free up capital for other priorities. Often a hotel owner does not have the luxury of being able to take advantage of inevitable market cycles, such as riding out a down market or being able to profit from a hot market. As such, sellers must assess that their initial capital structure may or may not allow for advantageous market timing and should consider exiting an asset while the overall climate is favourable rather than holding out for the ideal moment that may or may not maximise the return on investment.

\section{THE LANSDOWNE RESORT CASE STUDY}

\section{The property}

The Lansdowne Resort is located in Leesburg, Virginia, just outside Washington DC, near Dulles International Airport. The resort is a 297-key, full-service, four-diamond conference centre resort featuring 45,000 square feet of meeting space, an 18-hole championship golf course, several restaurants, a health club and spa and other resort amenities. The distinguishing feature of the property is its meeting space, which features numerous fixed-wall, dedicated meeting rooms, a 120 -seat amphitheatre, extensive audio- 
video capabilities and a dedicated staff focused solely on the meetings taking place in the conference centre. The resort opened in 1991 and is considered one of the top conference facilities in the USA.

The owners of the resort recently spent several years assembling land to add a second 18-hole golf course and clubhouse. The new golf course was designed by notable golfer and designer Greg Norman. The plan also entailed combining the two golf courses into a private club, which would be owned by the resort. A membership programme had been initiated and membership sales began in 2002, despite the fact that the new golf course was not expected to open until 2005, with the new clubhouse to follow.

\section{The transaction}

The ownership was a private investor, Stone Financial Group, the principals of which had owned Lansdowne Resort since the property opened in 1991. They had endured numerous market cycles, as well as multiple ownership structures and partners. They had skilfully utilised various capital structures to weather the market cycles and effectively exit various partners, while still maintaining control of the asset. But the resort represented a significant portion of the financial resources of the current owner and the asset was at a crossroads. To bring the asset to the next level and effect the expansion via the second golf course and clubhouse would take considerable additional investment, in excess of $\$ 24 \mathrm{~m}$. They had also utilised creative mezzanine financing to consolidate the ownership of the resort, but as such the property had debt against it that provided an obstacle to gaining additional debt to fund the expansion. It was determined that a partner was needed to provide additional capital to the ownership so the property could be expanded and realise its true potential.

In February 2003, HREC Investment Advisors, in conjunction with a strategic partner, Greenwich Group International, were retained to seek out an equity partner. During the course of the investment banking assignment it became clear that certain tradeoffs would be involved in bringing in a capital partner, principal of which would be the loss of control of the ownership group. As such, a strategic decision was made to sell the asset instead of proceeding with a joint venture. In June 2003 the resort was sold to LaSalle Hotel Partners for $\$ 115.8 \mathrm{~m}$, or approximately $\$ 390,000$ per key. The price paid represented an approximate capitalisation rate on trailing 12-month NOI of 8 per cent. At the time, and for much of 2003, this transaction was the largest single asset sale in the USA, and represented one of the highest prices per key paid for an asset in the USA in some time. It was one of the first trophy assets to be brought to market since the events of 11 September, 2001 and is a good indicator of how both sellers and buyers are currently structuring transactions in the face of market uncertainty. 


\section{Transaction milieu}

\section{Transaction challenges}

The resort had been the beneficiary of skilled ownership and management, with operating results that were enviable. In the year 2000 , NOI had exceeded $\$ 12 \mathrm{~m}$, but the economic decline in 2001, and more specifically the tragic events of September 11th, had a dramatic impact on the operations of the resort, with a decline in cash flow of almost 40 per cent. The resort had rebounded strongly in 2002, increasing cash flow by 20 per cent over 2001 numbers. But the cash flow fluctuations made the ownership very aware of how vulnerable they were to events well outside of their control, and how much personal exposure they had in this single asset.

Numerous challenges faced the transaction, including educating the investor community about the conference centre concept, as many investors either did not understand the concept of a full American plan (FAP - whereby a meeting attendee pays one price for use of hotel room, meeting space, meals and breaks), or thought that the property was vulnerable to competition from hotels offering services à la carte.

Another transaction challenge was the development aspects of the property, in that in order to realise the true upside of an investment in this asset, an investor would need to embrace two ongoing initiatives: the development of the second golf course, clubhouse and golf membership programme, and a thoughtful exploration of how best to utilise 240,000 square feet of development rights that came as part of the transaction. Many investors are adverse to taking development risk, and as such many investors explored the possibility of spinning out the core hotel asset from the transaction, and having the current owner retain the existing golf course and land for the new golf course.

An additional challenge facing the transaction was the price per key. With a target price approaching $\$ 120 \mathrm{~m}$, this value equated to in excess of $\$ 400,000$ per key. Granted, the price included a golf course and extensive development parcels and rights, but it still concerned investors, with the key issue being how a new investor was going to exit the asset at a profit when the initial basis was perceived to be high. It also put additional focus on the golf membership programme as an important revenue source during the hold period, as some investors believed they might not exit the investment at a value much above their initial basis.

Another obstacle facing the transaction was the current debt on the property. The current first mortgage loan was approximately $\$ 59 \mathrm{~m}$, and was placed on the asset shortly after the events of September 11th. While considered a good loan at the time, particularly in light of the limited debt capital available to hotels after September 11th, it proved to be a challenging factor in terms of a sale for several reasons. The note was not prepayable until January 2004, and as such would need to be assumed by a new investor. This presented two challenges: the degree of leverage to the purchase price was inefficient and would hence require a 
substantial equity investment by a new owner, and secondly, the current interest rate was well above current market rates. These factors would limit the initial return to an investor, and as such had an impact on the value of the asset.

Not the least of the challenges facing the transaction was the timing of the offering, as the property was brought to market on the eve of the 2003 Iraq conflict, which had the effect of making conservative investors even more conservative, and essentially eliminated potential investment from targeted European investors due to the tension at the time between the USA and several European allies.

\section{The deal}

While in excess of 100 investment groups expressed interest in this trophy asset, there was an active pursuit and investigation of the opportunity by only approximately 20 investment groups. One of the more aggressive investors was LaSalle Hotel Properties of nearby Bethesda, Maryland. LaSalle is a hotel REIT with a portfolio of 17 full-service hotels, ranging from resort properties to boutique hotels. Its senior management is comprised of savvy and experienced hotel investors who have embraced certain contrarian hotel plays such as boutique hotels and development as a means to generate returns to their investors. LaSalle was coming off the sale of a major asset in New Orleans and needed to effect a 1031 tax exchange in a short period of time in order to avoid unnecessary tax consequences. As such, they were aggressive in their pursuit of Lansdowne. An initial discussion about a joint venture with the current ownership was explored, but as it became clear that the current owner would lose day-today control of the asset in such a scenario, it was decided by both parties that an outright sale was more advantageous for all involved. A sale price of $\$ 115.8 \mathrm{~m}$ was negotiated, with certain additional proceeds to come to the seller in the event that certain out parcels and development rights were sold to an adjacent property owner. Due diligence was thorough, but swift, and the transaction closed in June 2003. It also helped that one of the key executives of LaSalle had formerly been in the employ of the key principal on the sell side, and had direct experience with the subject property. As such, a certain amount of trust was established between the parties, which proved to be a facilitating point during the negotiations.

In the end, the seller was able to achieve their diversification goal, while achieving a good value for the asset. The buyer was able to take advantage of their liquidity, local presence and industry expertise to circumvent the marketing process with a pre-emptive bid. Besides the direct investment benefits of the asset itself, it also gave them a major asset to showcase to their investors that was in close proximity to their corporate headquarters, and as such also enabled them to achieve a macro benefit from the transaction. 


\section{Lessons learned}

In reviewing the Lansdowne transaction, both buyer and seller utilised the strategic skills discussed earlier to impact on this transaction.

\section{The seller}

- Enhanced value via development. The ability to acquire and entitle the excess land for the second golf course and clubhouse, as well as the acquisition of the 240,000 square feet of excess density, not only created a viable area for expansion, but it increased the value of the asset by offering a clear upside to a new owner.

\section{Seller's goals}

\section{Buyer's goals}

- Superior operating skills to create value. The Stone Financial Group as asset manager, and Benchmark Hospitality as property manager, employed their expertise and vision to create a significant cash flow at the asset, which in turn provided the base return investors were seeking.

- Create value by embracing risk. Developing an asset of the stature of Lansdowne is inherently risky, but so is increasing leverage to exit a partner. Stone mitigated these risks by careful examination of the market, both capital markets and hotel markets, to make informed decisions on the direction of the asset for every step of the way.

\section{The buyer}

- Utilise lower cost of capital to create value. LaSalle has access to capital at rates below traditional levels of conventional, singleasset-based debt. Additionally, their yield parameters are well within the reality of investing in today's hotel market, and as such they can utilise their financial strength both to acquire key assets and to produce excellent risk-adjusted returns for their investors.

- Utilise superior investing skills to create value. LaSalle's ability quickly to absorb the nuances of a complex asset and transaction gave them a competitive advantage in the transaction, as this allowed them to come quickly to decisions, make prompt decisions and pre-empt the overall marketing process by aggressive action, backed by sound analysis.

- Create value by embracing risk. As with Stone, LaSalle was not adverse to a calculated risk - in their case it was the risk of development. The seller calculated that developing the second golf course, clubhouse, spa, golf membership programme and other opportunities at the resort represented too great a personal risk. The buyer viewed these same risks as an opportunity to take the asset to another level, and as such produce even better cash flows at the property.

\section{The seller and buyer speak}

Michael Stone of the Stone Financial Group, the seller, comments on the asset and the transaction. 
'Lansdowne is a lesson in strategic financing: essentially we had to own this asset three different times. Originally the hotel was financed to get it built, then refinanced to increase our leverage via a mezzanine debt and preferred equity vehicle that allowed us to exit a Japanese partner, and again after 9-11.

It is also a lesson in adaptation, in that the original owner was VMS Realty, and our partner in VMS was Xerox, which had planned to build 11 million square feet of office space in the immediate area when the hotel was built. This office space was never built, and the Loudon County area took ten years to turn into the type of dynamic market we always thought it was going to be. We were able to exit our Japanese partner at close to par and gain their 84 per cent interest in the asset. It should also be remembered that when the Japanese were making major investments in US real estate there was a yen currency play and their cost of capital was very low. As such, our Japanese partners most likely did make a profit on the transaction, but essentially the whole transaction was done with other people's money, while we were always able to hold control over the general partnership and asset management of the property.

We were able to add value also at the property level by adding a spa, and thus riding the health and fitness wave. We added a wine cellar and sommelier to take advantage of dining trends and improve the image of the resort. We also did an evaluation of the conference business in 1994/1995 and decided to evolve away from a pure conference centre to a conference resort, enabling us to diversify our group market mix, increase our transient business and take advantage of macro meeting and leisure trends. Thus we made Lansdowne a unique asset for our target market.

We believed in this deal, but needed to make a significant capital investment in order to reap the future rewards, but the risk was too high for a closely held private entity. In summary, you have to know when to say goodbye, put ego aside and look at the facts, ie capital requirements versus risk. You also realise, while your country is at war, how vulnerable you are to external factors, and as such I feel we made the right decision at the time to exit this investment.'

Mike Barnello, chief operating officer of LaSalle Hotel Properties, the buyer, comments as well.

'LaSalle Hotels' goal is to find assets that are income focused and look for moderate growth, we balance what we can buy today in the hotel world with how long you have to wait for income growth. In short, we look for opportunistic investment in high-quality assets, and Lansdowne was an ideal candidate for that strategy.

We intend to pick up where Stone left off, complete the second golf course, keep Greg Norman as the designer, upgrade the hotel to match the upgrade in the resort facilities and do the clubhouse 
development simultaneously with the golf course. In addition, we are going to expand the spa from 2,000 square feet to $10,000-$ 12,000 square feet, in order to offer a real spa experience. We feel that the expanded and upgraded facility will continue to position Lansdowne as a unique choice for guests.

What appealed to us about Lansdowne was the strong current income of the asset, the opportunity for growth and the location in a booming market relative to other parts of Virginia and the USA in general. We also liked that the resort was unencumbered by management and flag, giving us the ability to make a change if so desired (in fact, the existing property manager, Benchmark Hospitality, was retained as the operator of the resort).

As a REIT, we do not look to sell on a set time frame. Instead, we do a five-year hold analysis from both a leveraged and an unleveraged perspective. We re-evaluate this analysis every year to take advantage of market conditions.

How did we prevail in the pursuit of a very desirable asset? I feel that our ability to embrace complexity gave LaSalle a competitive advantage in the acquisition of this asset.'

\section{Reference}

1. See Stoesser, J. W. and Hess, R. C. (2000) 'Differentiating higher return strategies in property markets', Prudential Real Estate Investors Research, August. 